\title{
Courts Caught in Conflict? Institutional Trust and Social Conflict
}

\author{
Tribunais pegos em conflito? Confiança Institucional e Conflito \\ Social
}

Joseph M. Cox ${ }^{l}$

\begin{abstract}
:
According to positivity theory, the public's exposure to the American judicial system and the judiciary's unique set of symbols and processes tends to lead individuals to confer on the institution legitimacy and trust through mechanisms often not available to other political actors. This paper focuses on whether this theory operates outside of the American context, arguing that the legitimacy conferred by domestic audiences upon domestic judiciaries will be less variable than the legitimacy reposed in other governing actors. However, moving to a comparative context implicates a number of potentially additional factors, including the influence of variation across regime-types, legal systems, and issue areas. Are courts inherently unique, as suggested by positivity theory, or does the resiliency of courts vary across different institutional contexts? In order to answer this question, this study leverages survey data from the Latinobarómetro and the Afrobarometer to measure levels of public trust in several governing institutions, including, but not limited to, the judiciary, the executive, and the legislature, to analyze whether institutional legitimacy varies across different governmental actors in the presence of public opposition to government policy or across different legal institutional contexts. Public discontent with policy is measured using data coded by the Social Conflict Analysis Database, which identifies instances of demonstrations, riots, and strikes. As a measure of the institutional context within which a judiciary operates, the analyses leverage a latent variable of judicial independence created by Linzer and Staton (2015). The paper's statistical analyses provide evidence to support the distinctiveness of judiciaries, finding that social conflict can impact negatively public trust in executives and legislative institutions, yet exert no influence on public trust in judiciaries. Furthermore, the empirical results indicate that high levels of judicial independence can be converted to higher levels of trust in the judiciary.
\end{abstract}

\section{KEYWORDS:}

Social Conflict; Institutional Trust.

\section{RESUMO:}

De acordo com a teoria da positividade, a exposição do público ao sistema judicial americano e o conjunto de processos do Judiciário tendem a levar os indivíduos a conferir, à instituição, legitimidade e confiança por meio de mecanismos frequentemente não disponíveis para outros atores políticos. Este artigo enfoca se essa teoria opera fora do contexto americano, argumentando que a legitimidade conferida pelo público doméstico aos judiciários domésticos será menos variável do que a legitimidade depositada em outros atores. No entanto, mudar para

\footnotetext{
${ }^{1}$ Joseph M. Cox is a Ph.D. candidate studying international relations at the School of Government and Public Policy at the University of Arizona. He wishes to thank Chad Westerland, Faten Ghosn, and Jessica Maves Braithwaite for their feedback throughout the process of writing this article.
} 
um contexto comparativo implica uma série de fatores potencialmente adicionais, incluindo a influência da variação entre tipos de regime, sistemas legais e áreas temáticas. Os tribunais são inerentemente únicos, conforme sugerido pela teoria da positividade, ou a resiliência dos tribunais varia em diferentes contextos institucionais? Para responder a essa pergunta, este estudo utiliza dados de pesquisa do Latinobarômetro e do Afrobarometer para medir níveis de confiança do público em várias instituições governamentais, incluindo, entre outros, o Judiciário, o Executivo e o Legislativo, para analisar se os institucionais a legitimidade varia entre os diferentes atores governamentais na presença de oposição pública à política do governo ou em diferentes contextos institucionais legais. $\mathrm{O}$ descontentamento público com a política é medido usando dados codificados pelo Social Conflict Analysis Database, que identifica instâncias de manifestações, tumultos e greves. Como uma medida do contexto institucional no qual um judiciário opera, as análises alavancam uma variável latente de independência judicial criada por Linzer e Staton (2015). As análises estatísticas do artigo fornecem evidências para apoiar a distinção dos magistrados, descobrindo que o conflito social pode impactar negativamente a confiança do público em executivos e instituições legislativas, mas não exerce influência sobre a confiança do público nos magistrados. Além disso, os resultados empíricos indicam que altos níveis de independência judicial podem ser convertidos em níveis mais altos de confiança no judiciário.

\section{PALAVRAS-CHAVE:}

Conflito Social; Confiança Institucional.

Despite being a coordinate branch of government alongside the executive and the legislature in many states, courts are often perceived to be set-off from the vicissitudes of politics and political calculations (Gibson, et al. 2014; Segal and Spaeth 2003). In the literature leveraging the United States as a focal case, many studies adduce considerable evidence to suggest that the institutional loyalty and support for the United States Supreme Court (the "Court") shields the judiciary from dramatic reductions in public support potentially at risk due to judicial decisions running contrary to the citizenry's policy preferences (see, e.g., Gibson and Nelson 2015). Often termed diffuse support, scholars argue that the loyalty many Americans harbor for the Court functions as a tool to force acquiescence to and implementation of judicial rulings by the political branches of government as well as acting as a shield against incursions from external actors (Gibson and Nelson 2015; Gibson and Caldeira 2009; Staton 2006; Vanberg 2001). A strain of the literature further proposes that the Court's position in society and its perception among the public affords it the ability to shape public opinion through its decisions (Franklin and Kosaki 1989; but see Mishler and Sheehan 1993). Ultimately, the Court is a constitutional institution reflecting one aspect of American society, and over its life, the Court has carved its place in the edifice of the American democratic system (Crowe 2012). 
However, the existence of similarly-situated courts in different political systems and environments are alleged not to have fared as well as the Court (Ruibal 2009; Moustafa 2007; Helmke 2012, 2002). Other courts have struggled to secure the institutional loyalty enjoyed by the Court (Gibson 2016; Gibson and Caldeira 2003). Yet, we observe courts in the global community acting strategically and seeking to leverage similar tools to the Court when challenging the actions of other political actors, both at the domestic level (Krehbiel 2016; Ruibal 2009; Staton 2006; Helmke 2012, 2002) and international level (Carrubba, et al. 2008). In light of this literature, should the American case be considered unique in judicial politics? That is, do domestic courts generally enjoy a special status setting them apart from other political actors in a polity?

As a test of the institutional uniqueness of judiciaries in a cross-national setting, this study focuses on a myriad of states ranging across different regime types and domestic legal traditions as the crucibles for discerning whether there is evidence of cross-national support for domestic judiciaries that contrasts with support for other political actors. By leveraging survey data from 8 Latin American states and 20 states in Africa, this paper analyzes whether trust in the judiciary is impacted by the occurrence of social conflict, identified as demonstrations, riots, and strikes. Furthermore, the study seeks to answer whether different institutional contexts influence the willingness of domestic populations to support their judiciaries, with a particular focus on the variation across states in terms of their differential levels of judicial independence. The subsequent analyses find evidence that increased numbers of social conflict events often have a negative impact on the public's trust in the political institutions of government, yet the analyses yield no clear evidence of any effect on the public's view of the judiciary. Furthermore, the regression analyses provide initial evidence indicating that higher levels of judicial independence translate into greater support for the judiciary. From these findings, we can infer that courts are viewed as distinct institutions set apart from the political institutions of government, and the unique status of domestic judiciaries potentially shields them from threats to institutional loyalty.

\section{THE AMERICAN JUDICIARY AND THE IMPORTANCE OF LEGITIMACY}


Although the Court has become an indelible, coordinate branch of the American national government, its place in the constitutional structure finds its genesis in the wake of the constitutional articles creating and outlining the powers of the political branches of Congress and the presidency. The Court has neither the power of the purse nor of the sword; it looks to Congress for logistical support and, typically, to the executive for the implementation of judicial rulings (Hall 2011; Hamilton [1788] 2009). Its members enjoy life tenure after appointment to the Court and confirmation to the post by the Senate ${ }^{2}$; the justices hear cases on a multitude of issues bearing on public policy, from the mundane to the transformative; and they sit as the final arbiters on the interpretation of the constitution and the application of its precepts (Segal and Spaeth 2003). Given the insulation of the Court from the political process of elections alongside its power of judicial review, many view the Court as a counter-majoritarian institution (Mishler and Sheehan 1993; Bickel 1962); nevertheless, many studies find evidence reflecting the importance of an independent judiciary to a functioning democracy (Gibler and Randazzo 2011; Larkins 1996; Linz and Stepan 1996). Although the Court reviews most forms of government action with the power to overrule the pronouncements of the other branches of government, the common law system within which the Court is embedded purports to constrain the justices' decision making via means of precedent, that is, justices render an opinion based upon the manner by which case law, which is generated through rulings on previous cases with factual and legal similarities, overlays the facts of the immediate case (Mitchell and Powell 2011; Bailey and Maltzman 2011). Precedent is accompanied by arcane and, often, complex legal rules, procedures, and reasoning that buttress the arguments and decisions set forth by the Court in its opinions (Fox and Vanberg 2014; Bartels 2009). In essence, legal reasoning supplants political expediency in judicial decision making. ${ }^{3}$

\footnotetext{
${ }^{2}$ Although certain American states provide for the election or retention of judges and justices through popular referenda, the opening of the judiciary to the political process does not necessarily negate the unique status of courts in the minds of Americans. Since state courts still employ many of the trappings, symbols, and procedures underlying the causal mechanism identified by positivity theory (Gibson, et al. 2014; Gibson and Caldeira 2009), state courts can still engender diffuse support even when elections draw the courts closer to the political branches, at least in terms of the process by which justices and judges are selected for the position they hold.

${ }^{3}$ The literature on judicial decision making is often divided along three theoretical orientations: the legal (Bailey and Maltzman 2011), the attitudinal (Segal and Spaeth 2003), and the separation of powers frameworks (Segal 1997). Although scholars have found evidence to support aspects of the legal framework (Bailey and Maltzman 2011; Bartels 2009), the weight of the evidence tilts toward the attitudinal and separation of powers models (Segal, et al. 2011; Clark 2009; Segal and Spaeth 2003). In this paper, I need not delve into the judicial decision-making debate as the study centers on how different publics view their domestic courts, which does not necessarily rely on a specific framework within which to understand the decision making of the members of those domestic courts. Rather, the crux of this study turns on the perception of courts and whether the legal model operates to set domestic courts apart from their political counterparts in the minds of those in the citizenry.
} 
The instrumental purpose of the judiciary in the American system of government combined with its asserted reliance on legal doctrine as the foundation of judicial decision making conjures an institution standing in stark contrast to the presidency and the Congress. Yet, the perception of the judiciary's uniqueness in American life is bolstered by the institution's descriptive characteristics, as well. Gibson, et al. (2014: 840-841) describe the power of judicial symbols in setting the judiciary apart from the other coordinate branches of government:

\begin{abstract}
When citizens pay attention to judicial proceedings, they are bombarded with a host of specialized judicial symbols, typically beginning with the court building itself . . . and proceeding through special dress for judges (robes), and honorific forms of address and deference ("your honor"), directed at a judge typically sitting on an elevated bench, surrounded by a panoply of buttressing symbols (a gavel, the blindfolded Lady Justice, balancing the scales of justice, etc.). These judicial symbols frame the context of court decisions and seem to convey the message that courts are different from ordinary political institutions; that a crucial part of that difference is that courts are especially concerned about fairness, particularly procedural fairness; that because decisions are fairly made, they are legitimate and deserving of respect and deference; and consequently [sic] that a presumption of acquiescence attaches to the decisions.
\end{abstract}

Assuming arguendo these characteristics of the judiciary separate it from the presidency and Congress, what value do they provide the judiciary? According to positivity theory, promulgated by Gibson and Caldeira (2009), the public's exposure to the symbols, processes, deliberations, and decisions of judicial actors generates, increases, and sustains the legitimacy of the institution. Without the ability to implement its own decisions, the judiciary must rely on the power of other political actors, and it can wield its legitimacy, as a function of public support for the institution, as the cudgel with which to ensure implementation and compliance with the judiciary's rulings (Krehbiel 2016; Staton 2006; Vanberg 2001). Thus, the creation and maintenance of the judiciary's legitimacy in the eyes of the public is a necessary ingredient to the continued strength and salience of American courts in American democracy.

This process necessarily raises a question as to how variable the American judiciary's legitimacy can be. In the abstract, positivity theory could be interpreted to suggest a deterministic path from exposure to judicial proceedings to high levels of institutional legitimacy (Gibson, et al. 2014; Gibson and Caldeira 2011; but see Gibson and Caldeira 1992). However, scholars draw a distinction between two forms of public support: diffuse support and specific support. Diffuse support, which is often treated as synonymous with legitimacy, is institutional support that varies little regardless of an individual's agreement with a particular opinion; in other words, if the Court issues an opinion contrary to the policy preferences of an 
individual harboring high levels of diffuse support for the Court, the individual will likely continue to support the Court despite his or her disagreement with the decision (Gibson and Nelson 2015). Specific support, on the other hand, refers to a more fluid view of the Court's practices predicated on performance, indicating that the individual's support for the Court varies based upon the convergence of his or her policy preferences with the Court's decisions (ibid.). Given the solidity of diffuse support, courts should prefer high levels of diffuse support rather than specific support, and the distinction is not trivial. If courts rely on public support for the continued prominence and influence of the judiciary in American politics, diffuse support is much more apt and effective at bolstering the judiciary's strength and ensuring implementation and compliance with judicial rulings. In fact, qualitative evidence shows how sensitive the Court's justices can be to public sentiment and the maintenance of diffuse support for the Court (Clark 2009). In sum, while the American judiciary enjoys an array of powerful tools to impact public policy, its continued power relies heavily on the strength of its rapport with the American public, and justices remain cognizant of the delicate position courts have in the American psyche and remain committed to fostering and maintaining high levels of diffuse support.

\section{JUDICIAL LEGITIMACY IN THE GLOBAL COMMUNITY}

As Ginsburg and Moustafa (2008) describe, the twentieth century has witnessed a rise in the judicialization of politics. An increasing number of states in the global community have created and empowered courts so they may incur a greater responsibility and involvement in the affairs of the state (Moustafa 2014; Helmke and Rosenbluth 2009; Ginsburg and Moustafa 2008). While effective courts are often presumed to be found only in democracies (Moustafa 2014; Helmke and Rosenbluth 2009), a wealth of literature has grown to show how courts can be effective for certain purposes in autocratic states, providing benefits to the regime in the form of bureaucratic oversight, provision of political cover, and the encouragement of foreign direct investment (Wang 2015; Ginsburg and Moustafa 2008; Moustafa 2007). Nevertheless, the judiciary must remain strategic in ruling against other political actors in the system in order to maintain a certain level of independence and influence because, for example, the support of the public in a regime that forecloses political dissent or opposition forecloses the potential for 
courts to leverage public outcry as a form of institutional strength (Helmke 2012, 2002; Moustafa 2007).

Yet, even in unstable democracies, in which competitive elections offer the potential for political turnover, institutional legitimacy can be wielded by courts as a means to secure compliance with their decisions. Thus, the question is whether the findings with respect to institutional legitimacy in the American context translate to a comparative setting. A preliminary answer, at least from the perspective of judicial actors, locates support in a number of studies that find evidence of courts seeking to leverage public sentiment to challenge effectively the actions of the political branches of government (Krehbiel 2016; Staton 2006; Vanberg 2004).

The effectiveness of courts in stable and unstable democracies is not without consequence. Given the importance of economic reconstruction or development following civil war, the investment inspired by domestic courts prepared and able to protect property rights can be an indelible tool for states seeking peace and stability (Flores and Nooruddin 2009; Moustafa 2007; Widner 2001). Additionally, fledgling democracies often rise from the ashes of an autocracy during which rampant human rights abuses occurred, and courts can offer a refuge for victims to seek recompense and issue rulings that act as deterrents for future abuses (Loyle and Appel 2017; Dancy and Michel 2016; Michel and Sikkink 2013; Sikkink 2011). In fact, studies find independent judiciaries to be a vanguard against human rights abuses in a variety of contexts (Mitchell, et al. 2013; Keith 2012; Powell and Staton 2009). Yet, court decisions cannot be enforced absent the intervention of other political actors; therefore, they require mechanisms to ensure compliance with their rulings (Krehbiel 2016; Clark 2009). Thus, domestic courts throughout the global community have an incentive to foster public support that is relatively unbreakable, which can be leveraged against a recalcitrant executive or legislature seeking to avoid the strictures of judicial decrees. However, the incentive of judicial actors to seek support is separate from the public's willingness to repose its trust in the institution. One means to test whether domestic courts can engender support from domestic audiences is to see whether these audiences equate their judiciaries with the political actors in the government, and the crucible for testing this proposition can be located in the reaction to governing institutions in the face of social conflict in the domestic arena (Levi, et al. 2009; Caldeira and Gibson 1992). 
While the genesis of certain social conflict events can occur in the absence of government activity, one subset of conflict events is directed at government actors in response to a particular action or omission attributed to the state (Salehyan, et al. 2012). However, engagement in demonstrations, riots, or strikes requires domestic audiences to overcome collective action problems, and grievances lodged against the government serve as one means to solve the inherent dilemma arising from the necessity of collective action (see Gates, et al. 2016; Aspinall 2007; but see Collier and Hoeffler 2004; Fearon and Laitin 2003). If domestic audiences engage in social conflict against the government to redress specific grievances, we should expect the public's view of political institutions - the actors with the power to affect directly public policy and address the public's concerns - to suffer, as the genesis of the grievances is likely to be found in either government activity or omission. If domestic courts are viewed as residing in a position outside the active mode of policy promulgation, social conflict directed toward a state's government should not impact the public's trust reposed in the judiciary; however, if the judiciary is viewed as one aspect of a unified government, its support with the public should be diminished in the midst of social conflict. Thus, the context of social conflict provides an effective means by which to test whether domestic courts in different political contexts enjoy a reservoir of goodwill shielding them from the fluctuations of the political process. The theoretical expectations yield the following hypotheses:

\section{Hypothesis 1: The occurrence of social conflict will not affect public trust in the} judiciary.

Hypothesis 2: The occurrence of social conflict will have a negative impact on the public's trust in the executive and the legislature.

Although social conflict may reflect underlying grievances against the state sufficient to diminish public trust in the government, the governing actors of a state exist in a particular institutional context that may also exert an influence on the levels of trust reposed in the state's institutions (Boateng and Adjorlolo 2018; Gibson and Caldeira 2009). If social conflict directed at government actors occurs as a result of public policy spurring grievances among the public, the institutions most likely to be held accountable are the political branches that promulgate policy, as the previous discussion addressed. Thus, institutional characteristics that more clearly delineate between judicial and non-judicial actors should also influence the degree to which the public reposes its trust in the judiciary. The salient characteristic with the potential to exert this 
effect is the degree to which domestic judiciaries are independent from the influences of nonjudicial actors. If domestic courts enjoy a high level of institutional independence, the public should be more likely to distinguish between the judiciary and the non-judicial institutions when directing their ire against those enacting public policy to which the public disagrees (see Boateng and Adjorlolo 2018; Driscoll and Nelson 2018; Walker 2016; Salzman and Ramsey 2013; Kapiszewski 2012; Buhlmann and Kunz 2011). If so, we should expect higher levels of public trust in the judiciary in states with high levels of judicial independence relative to states with low levels of independence, leading to the following hypothesis:

Hypothesis 3: States with high levels of judicial independence will exhibit high levels of trust in their judiciaries.

\section{RESEARCH DESIGN}

As described in the literature, institutional legitimacy emanates from individuals, groups, and citizenries. It is loyalty and support directed toward an institutional structure. Since the sine qua non of legitimacy resides with individuals, an apt measure for such a concept is survey data, and a multitude of studies focused on defining the contours of institutional legitimacy, including judicial legitimacy, leverage survey data as measures of both diffuse and specific support (Gibson and Nelson 2015; Bartels and Johnson 2013). The present study follows this approach, using survey data generated by the Latinobarómetro (Latinobarómetro report, 2010) and the Afrobarometer (Carter 2010).

The first group of survey data leveraged in this study is taken from the 2010 round of the Latinobarómetro, which has produced survey data for 21 separate rounds beginning in 1995 . In order to test the effects of public trust in the judiciary and political institutions of the state, I focus on three particular questions on the 2010 survey instrument, asking respondents to record their level of trust in their state's domestic judiciary, the legislature or parliament, and the resident political parties. Survey respondents could select from four choices: high levels of trust (1), some trust (2), a little trust (3) or the lack of trust (4) (Latinobarómetro 2010). For the forthcoming analyses, I invert this scale so that high levels on the variable indicate a lot of trust in the institution and low values on the variable denote distrust in the institution. Although the Latinobarómetro provides survey data for respondents in a number of states, I use data only from those eight states that have available data in the Social Conflict Analysis Database 
(Salehyan, et al. 2012), which is used as one of the main independent variables. Table 1 presents the mean levels of trust in the judiciary and political institutions of the states in the sample.

Table 1: Average levels of trust in different institutions (sample of Latin American states)

\begin{tabular}{c|c|c|c}
\hline & $\begin{array}{c}\text { Trust in the } \\
\text { Judiciary }\end{array}$ & $\begin{array}{c}\text { Trust in the } \\
\text { Legislature or } \\
\text { Parliament }\end{array}$ & $\begin{array}{c}\text { Trust in the } \\
\text { Political Parties }\end{array}$ \\
\hline Costa Rica & 2.43 & 2.50 & 1.89 \\
\hline Dominican Republic & 1.97 & 2.03 & 1.84 \\
\hline El Salvador & 1.98 & 2.04 & 1.88 \\
\hline Guatemala & 1.87 & 1.94 & 1.73 \\
\hline Honduras & 2.17 & 2.29 & 1.90 \\
\hline Mexico & 2.06 & 2.10 & 1.84 \\
\hline Nicaragua & 1.89 & 1.86 & 1.73 \\
\hline Panama & 2.15 & 2.17 & 2.04 \\
\hline
\end{tabular}

Although four of the states in the sample have a mean response that reaches the level of a little trust in the judiciary, the remaining states have a mean in the area of distrust for the judiciary. This contrasts slightly with public trust in the legislature or parliament, which shows slightly higher levels of trust relative to the levels of trust in the judiciary.

The Afrobarometer has generated seven rounds of survey data from representative samples for select countries in Africa, beginning with the first round in 1999 and continuing through to the seventh round in 2018. In comparing the effect of social conflict and institutional factors on the degree of institutional legitimacy afforded state institutions, I leverage a set of five questions from the fourth wave of the Afrobarometer survey conducted in and around 2010, inquiring into each respondent's level of trust toward their state's executive, legislative institution, judiciary, ruling party, and opposition party (Carter 2010). Each respondent can select from four choices: " $0=$ Not at all, $1=$ Just a little, 2=Somewhat, [and] 3=A lot" (Carter 2010: 24-26). Table 2 provides a brief overview of the mean levels of responses for each of the five questions across the 20 states in the sample.

Table 2: Average levels of trust in different institutions (sample of states in Africa)

\begin{tabular}{c|c|c|c|c|c}
\hline & $\begin{array}{c}\text { Trust in the } \\
\text { Judiciary }\end{array}$ & $\begin{array}{c}\text { Trust in the } \\
\text { Legislature } \\
\text { or } \\
\text { Parliament }\end{array}$ & $\begin{array}{c}\text { Trust in the } \\
\text { President }\end{array}$ & $\begin{array}{c}\text { Trust in the } \\
\text { Ruling } \\
\text { Party }\end{array}$ & $\begin{array}{c}\text { Trust in the } \\
\text { Opposition } \\
\text { Party }\end{array}$ \\
\hline Benin & 1.58 & 1.64 & 2.07 & 1.47 & 1.21 \\
\hline
\end{tabular}




\begin{tabular}{c|c|c|c|c|c}
\hline Botswana & 2.20 & 1.99 & 2.34 & 2.11 & 0.99 \\
\hline Burkina Faso & 2.01 & 2.08 & 2.34 & 1.83 & 1.60 \\
\hline Cape Verde & 1.67 & 1.54 & 1.51 & 1.38 & 1.33 \\
\hline Ghana & 1.75 & 1.89 & 2.22 & 1.99 & 1.49 \\
\hline Kenya & 1.42 & 1.55 & 1.73 & 1.45 & 1.99 \\
\hline Lesotho & 2.08 & 1.67 & 1.67 & 1.60 & 0.91 \\
\hline Liberia & 1.46 & 1.42 & 1.92 & 1.44 & 1.08 \\
\hline Madagascar & 1.31 & 1.61 & 1.88 & 1.60 & 0.80 \\
\hline Malawi & 2.27 & 1.70 & 2.39 & 2.07 & 1.08 \\
\hline Mali & 1.41 & 1.85 & 1.93 & 1.70 & 1.43 \\
\hline Mozambique & 2.29 & 2.30 & 2.41 & 2.36 & 0.62 \\
\hline Namibia & 2.15 & 2.00 & 2.37 & 1.91 & 1.27 \\
\hline Nigeria & 1.33 & 1.15 & 1.44 & 1.05 & 1.07 \\
\hline Senegal & 2.14 & 1.24 & 1.46 & 1.14 & 1.31 \\
\hline South Africa & 1.86 & 1.49 & 1.30 & 1.51 & 1.19 \\
\hline Tanzania & 2.00 & 2.26 & 2.50 & 2.26 & 1.27 \\
\hline Uganda & 1.59 & 1.63 & 1.75 & 1.53 & 1.31 \\
\hline Zambia & 1.90 & 1.60 & 1.46 & 1.25 & 1.45 \\
\hline Zimbabwe & 1.59 & 1.71 & 1.21 & 0.95 & 1.88 \\
\hline & & & & & \\
\hline
\end{tabular}

As Table 2 indicates, there is considerable variation in states' levels of trust in their courts, with several states averaging responses in the "somewhat" category and others closer to the "none" category.

In this study, I am interested, in part, in understanding whether the public's view of its government changes based upon the degree of social conflict occurring within the state. Notably, this question does not implicate instances of civil war, interstate war, or internationalized civil war, as these environments likely present significantly different perceptions, concerns, and outcomes involving state actors and their actions or omissions (Salehyan and Linebarger 2014; Salehyan, et al. 2012). Therefore, a measure accounting for conflict events below the threshold of civil or interstate war is needed. To meet this need, the study leverages events-based data offered by the Social Conflict Analysis Database ("SCAD") (Salehyan, et al. 2012), which provides cross-national, time-series data on the occurrence of demonstrations, riots, strikes, and other forms of violence not rising to the levels of conventional measures of civil conflict ${ }^{4}$ (ibid.). As events-based data, SCAD creates a number of variables that account for the number, type, and target of social conflict events in a given state for a particular year. In order to understand the effects of social conflict events on

\footnotetext{
${ }^{4} \mathrm{SCAD}$ bases its coding procedures off the 25 battle-related deaths per year threshold described by the UCDP Armed Conflict Dataset (Gleditsch, et al. 2002).
} 
institutional trust, I use SCAD's variable that differentiates conflict events targeted at the central government from events not directed at the central government. In addition, I use another variable from SCAD that identifies events targeted at regional governments rather than those targeting the central government. In the subsequent analyses, I include separate count measures of both types of events.

In addition to the potential impact posed by social conflict, a public's perception of its judiciary could be influenced by the institutional context in which the judiciary acts. For example, many studies suggest that courts accrue institutional legitimacy and public support over time and through strategic behavior (Crowe 2012; Helmke 2012, 2002). These theories and empirics suggest that judicial effectiveness, which should be separated from substantive policy outputs, is related to the public trust reposed in the institution (Levi, et al. 2009). This is particularly the case if the public's interest in a strong judiciary is steeped in a conception of the courts as an institution with the power to constrain other political actors. If the court is ineffective, the public is less likely to be supportive of the institution because it cannot be trusted to perform one of its primary functions in a state's government. According to many scholars, the degree to which a judiciary is independent of other political actors is a measure of a judiciary's power (Linzer and Staton 2015). Although the conceptualization of judicial independence is an oft-debated topic, a standard approach centers on a judiciary's ability to render decisions in the absence of external influences as well as the likelihood of the judiciary's rulings to either constrain other political actors or be implemented by the political branches of government (Linzer and Staton 2015). Trust in an institution likely turns on its ability to carry out its primary mandates, and deficiencies in this regard should detract from the public's support for the institution. Furthermore, alongside the ability to fulfill the judiciary's obligations, high levels of independence clearly delineate the members and activities of the judiciary from other political actors in the system. Taken together, the institutionalization of judicial independence should impact the public's support of the judiciary. Therefore, the analyses leverage Linzer and Staton's (2015) measure of judicial independence, which is a latent variable of independence ranging from approximately 0 to 1 with higher values indicating higher levels of independence.

However, institutional trust likely does not turn solely on the vicissitudes of public discontent embodied by social conflict occurrences or the degree to which a domestic judiciary is independent from other political actors. Rather, institutional characteristics and state 
attributes likely condition the public's view of state institutions. In order to account for additional influences on institutional trust, the analyses include several control variables.

First, the judicial politics literature has adduced evidence to suggest that common law courts tend to be, on average, more independent than courts in civil law, Islamic law, or mixed law states (Mitchell, et al. 2013). Moreover, common law states are better able to constrain coordinate political actors and can better protect human rights, and the degree to which courts are able to curb state repression from other political actors likely impacts the public's trust in the institution (ibid.). To account for both domestic legal systems and levels of state repression, the analyses include measures of each. For domestic legal systems, I use Mitchell and Powell's (2011) data, which offer cross-national, time-series data on common law, civil law, Islamic law, and mixed law systems. The data denote the four different types of legal systems using binary indicators. Since the literature argues that common law systems are more likely to exhibit high levels of independence relative to non-common law systems, I set common law systems as the baseline category in the forthcoming analyses. As a measure of state repression, I leverage a latent variable constructed by Fariss (2014) that measures the level of physical integrity repression across time and space in order to account for the state's use of repressive tactics.

In addition, the legal institutional context within which a judiciary operates may be impacted by two other factors: (1) whether a state has a colonial history, which may shape the institutions that emerge in the wake of decolonization (Keith 2002); and (2) the state's regime type - courts tend to be less independent in autocratic states as compared to democratic states (Boateng and Adjorlolo 2018; Randazzo, et al. 2016; Moustafa 2014; Helmke and Rosenbluth 2009) and autocratic states are often more likely to engage in state repression as compared to democratic states (Law and Versteeg 2014; Poe, et al. 1999; Poe and Tate 1994). To control for a state's colonial history, the analyses leverage Hensel's (2014) data. ${ }^{5}$ In order to account for a state's regime type, I use the Polity index (Marshall, Gurr \& Jaggers 2018), which places states on a 21-point spectrum with strong autocracies denoted by a "-10" and strong democracies identified by a "10."

The forthcoming analyses include two additional structural variables that could influence the actions of a state's governing apparatus: the size of the state and the robustness of its economy. To account for a state's size, I include a measure of the total annual population

\footnotetext{
${ }^{5}$ Due to listwise deletion in the data, the colonial history variable lacks variation in the sample of Latin American states and, thus, I cannot include these data in the regression analyses. However, there is sufficient variation in the sample of states in Africa to include measures of colonial history in the analyses.
} 
for each state in the samples. In addition, I measure each state's economic status using annual GDP per capita data. The data for these variables is derived from the World Development Indicators (World Bank 2018). The effect of these two variables is likely to diminish at high levels, therefore, I transform each by taking the natural log of the base data and including the resulting values as two independent variables in the analyses.

However, structural characteristics are likely not the only potential confounding factors. In terms of the impetus for social conflict and the ability of domestic populations to overcome the barriers to collective action, both civil and social conflict may stem from public grievances against a state government (Gates, et al. 2016; Salehyan, et al. 2012). Thus, conflict may be the end result of unresolved grievances; as a result, grievances may directly impact a public's trust in governing institutions. According to the civil war literature, grievances may stem from ethnic divisions (see Gates, et al. 2016). Gibson (2016) also finds evidence that ethnicity may play a role in South Africans' views of their state's highest court. In order to account for the potential influence of ethnic cleavages, I use data from the Ethnic Power Relations dataset (Cederman, et al. 2010).

Given the structure of the aforementioned data, the unit of analysis in the forthcoming analyses is the individual survey respondent. As additional controls, in light of the unit of analysis, the regression analyses include the age and gender of each respondent. Moreover, since each dependent variable, across both surveys, is a four-category measure, the primary analyses use ordered logistic regression analysis to test the effects, if any, of social conflict events and legal institutions on the public's trust in the domestic judiciary. In order to avoid potential simultaneity bias and the concern of endogeneity, I lag each independent variable by a year in order to ensure that the instances of social conflict occur or particular institutional structures exist prior to each respondent's answers to the survey instrument. Lastly, I cluster the standard errors on each state across the samples used in the forthcoming analyses.

\section{ANALYSIS}

Although social conflict can occur in a variety of forms, the salient characteristic across conflict types is likely to be the target of the dissenters' ire, that is, conflict directed toward governing authorities likely stems from grievances against government action and should have a deleterious effect on the public's trust in the government. However, the courts 
should be shielded from the negative impact of social conflict due to their unique institutional characteristics. In line with existing, available data, I test this expectation in the institutional contexts of Latin America and Africa, with levels of trust toward Latin American institutions analyzed in Table 3 and similar analyses undertaken for select states from Africa in Table 4. Given the nature of the dependent variable, each model is estimated using an ordered logistic estimator.

Table 3: Ordered logistic regression results (sample of Latin American states)

\begin{tabular}{|c|c|c|c|}
\hline & Trust in the Judiciary & $\begin{array}{c}\text { Trust in the Legislature } \\
\text { or Parliament }\end{array}$ & $\begin{array}{c}\text { Trust in the Political } \\
\text { Parties }\end{array}$ \\
\hline $\begin{array}{c}\text { Central Government } \\
\text { Target } t_{t-1}\end{array}$ & $\begin{array}{l}-0.134 \\
(0.357)\end{array}$ & $\begin{array}{l}-0.255 \\
(0.214)\end{array}$ & $\begin{array}{c}0.008 \\
(0.053)\end{array}$ \\
\hline $\begin{array}{c}\text { Regional Government } \\
\text { Target } t_{t-1}\end{array}$ & $\begin{array}{c}0.153 \\
(0.302)\end{array}$ & $\begin{array}{c}0.267 \\
(0.180)\end{array}$ & $\begin{array}{c}0.022 \\
(0.045)\end{array}$ \\
\hline Judicial Independence $_{t-1}$ & $\begin{array}{c}6.542 \\
(6.159)\end{array}$ & $\begin{array}{l}9.436 * * \\
(3.676)\end{array}$ & $\begin{array}{l}-0.371 \\
(0.908)\end{array}$ \\
\hline Repression $_{t-1}$ & $\begin{array}{l}-0.215 \\
(1.068)\end{array}$ & $\begin{array}{l}-0.627 \\
(0.642)\end{array}$ & $\begin{array}{c}0.141 \\
(0.157)\end{array}$ \\
\hline Excluded Groups $_{t-1}$ & $\begin{array}{c}0.152 \\
(0.263)\end{array}$ & $\begin{array}{c}0.240 \\
(0.158)\end{array}$ & $\begin{array}{l}-0.016 \\
(0.039)\end{array}$ \\
\hline Polity $_{t-1}$ & $\begin{array}{l}-1.389 \\
(1.226)\end{array}$ & $\begin{array}{c}-2.028 * * * \\
(0.730)\end{array}$ & $\begin{array}{l}-0.202 \\
(0.184)\end{array}$ \\
\hline GDP per Capita $(\ln )_{t-1}$ & $\begin{array}{c}0.537 \\
(0.623)\end{array}$ & $\begin{array}{l}0.796^{* *} \\
(0.369)\end{array}$ & $\begin{array}{l}0.243 * * \\
(0.097)\end{array}$ \\
\hline Population $(\ln )_{t-1}$ & $\begin{array}{c}-0.638 * * * \\
(0.146)\end{array}$ & $\begin{array}{c}-0.905 * * * \\
(0.089)\end{array}$ & $\begin{array}{c}-0.437 * * * \\
(0.030)\end{array}$ \\
\hline Age of Respondent & $\begin{array}{l}-0.005^{*} \\
(0.003)\end{array}$ & $\begin{array}{l}-0.002 \\
(0.002)\end{array}$ & $\begin{array}{l}-0.002 \\
(0.003)\end{array}$ \\
\hline Gender of Respondent & $\begin{array}{c}0.074 * * * \\
(0.026)\end{array}$ & $\begin{array}{c}0.067 * * * \\
(0.025)\end{array}$ & $\begin{array}{c}0.033 \\
(0.042)\end{array}$ \\
\hline$N$ & 7,785 & 7,826 & 7,890 \\
\hline Log likelihood & -9492.081 & -9732.887 & -9107.872 \\
\hline
\end{tabular}

Clustered standard errors in parentheses

$* * * \mathrm{p}<0.01, * * \mathrm{p}<0.05, * \mathrm{p}<0.1$ 
In evaluating Hypotheses 1 and 2, the empirics in Table 3 reflect the expectations concerning government-targeted events on the trust publics repose in the political institutions of government, that is, the legislature or the parliament. However, the coefficient for central government-targeted events is negative in relation to trust in the judiciary, which runs contrary to the theory's expectation. However, neither effect reaches statistical significance at conventional levels, suggesting that the effect of social conflict on the public's trust in the judiciary is statistically indistinguishable from zero. This null finding provides initial support for the first hypothesis. However, the null finding regarding the effect of conflict on the public's trust in the legislature or parliament does not provide support for the second hypothesis. Interestingly, there does appear to be an institutional influence on the public's trust in governing institutions offered by the degree to which a state's judiciary is independent. As it relates to trust in the judiciary and the elected branches of government, higher levels of judicial independence increase the public's confidence in those institutions; however, only the coefficient for the public's trust in the legislature or the parliament reaches a conventional level of statistical significance. As an initial foray into speculating as to the effect of judicial independence on the public's trust in the elected branches of government, it may be explained through the role played by the judiciary, that is, if the judiciary is able to provide a constraint on the exercise of political power free from external influence, the public may have greater confidence in the political actors acting within the confines of the state's political order. Thus, issues generated by certain government action with the capacity to allow individuals to overcome collective action problems may spur social conflict yet not necessarily detract from the public's trust in the government because the disagreement does not concern political or constitutional transgressions but only disagreements over the choice of public policy.

In its current version, SCAD contains data only for eight Latin American states; however, it provides a larger dataset for a number of states in Africa. With an expanded sample afforded by greater data availability, I run similar models to those presented in Table 3 incorporating the SCAD data on the 20 states in Africa selected for the fourth round of the Afrobarometer survey, and the results are set forth in Table 4.

Table 4: Ordered logistic regression results (sample of states in Africa)

\begin{tabular}{ccccc}
\hline Trust in the & $\begin{array}{c}\text { Trust in the } \\
\text { Judiciary } \\
\text { Parlatiament }\end{array}$ & $\begin{array}{c}\text { Trust in the } \\
\text { President }\end{array}$ & $\begin{array}{c}\text { Trust in the } \\
\text { Ruling Party }\end{array}$ & $\begin{array}{c}\text { Trust in the } \\
\text { Opposition } \\
\text { Party }\end{array}$ \\
\hline
\end{tabular}




\begin{tabular}{|c|c|c|c|c|c|}
\hline Central & -0.006 & $-0.086^{* * *}$ & $-0.140 * * *$ & $-0.143 * * *$ & $0.055 * * *$ \\
\hline $\begin{array}{l}\text { Government } \\
\text { Target }_{t-1}\end{array}$ & $(0.011)$ & $(0.020)$ & $(0.015)$ & $(0.022)$ & $(0.015)$ \\
\hline Regional & $-0.672 * * *$ & $-0.484 * *$ & $-0.986 * * *$ & $-0.629 * * *$ & -0.131 \\
\hline $\begin{array}{l}\text { Government } \\
\text { Target }_{t-1}\end{array}$ & (0.093) & $(0.215)$ & $(0.115)$ & $(0.217)$ & $(0.175)$ \\
\hline $\begin{array}{c}\text { Judicial } \\
\text { Independence }_{t-1}\end{array}$ & $\begin{array}{c}1.609 * * * \\
(0.355)\end{array}$ & $\begin{array}{l}-0.556 \\
(0.509)\end{array}$ & $\begin{array}{c}1.631 * * * \\
(0.335)\end{array}$ & $\begin{array}{c}2.178 * * * \\
(0.502)\end{array}$ & $\begin{array}{c}-3.392 * * * \\
(0.433)\end{array}$ \\
\hline Civil Lawt-1 & $\begin{array}{c}-0.768 * * * \\
(0.116)\end{array}$ & $\begin{array}{c}2.094 * * * \\
(0.229)\end{array}$ & $\begin{array}{c}3.246 * * * \\
(0.184)\end{array}$ & $\begin{array}{c}2.601 * * * \\
(0.258)\end{array}$ & $\begin{array}{l}-0.303^{*} \\
(0.172)\end{array}$ \\
\hline Islamic Lawt-1 & $\begin{array}{c}1.026 * * * \\
(0.138)\end{array}$ & $\begin{array}{c}1.610 * * * \\
(0.232)\end{array}$ & $\begin{array}{c}3.959 * * * \\
(0.244)\end{array}$ & $\begin{array}{c}2.834 * * * \\
(0.259)\end{array}$ & $\begin{array}{c}-1.730 * * * \\
(0.186)\end{array}$ \\
\hline Mixed Law L $_{t-1}$ & $\begin{array}{l}-0.074 \\
(0.132)\end{array}$ & $\begin{array}{c}1.322 * * * \\
(0.304)\end{array}$ & $\begin{array}{c}2.646^{* * * *} \\
(0.226)\end{array}$ & $\begin{array}{c}2.284 * * * \\
(0.344)\end{array}$ & $\begin{array}{c}-0.984 * * * \\
(0.221)\end{array}$ \\
\hline Repression $_{t-1}$ & $\begin{array}{c}5.35 \mathrm{e}-07 \\
(4.63 \mathrm{e}-06)\end{array}$ & $\begin{array}{l}-0.00002 \\
(0.00001)\end{array}$ & $\begin{array}{c}-0.00008 * * * \\
(8.88 \mathrm{e}-06)\end{array}$ & $\begin{array}{c}-0.00006 * * * \\
(0.00001)\end{array}$ & $\begin{array}{c}0.00001 \\
(8.99 \mathrm{e}-06)\end{array}$ \\
\hline $\begin{array}{l}\text { Excluded } \\
\text { Groups }_{t-1}\end{array}$ & $\begin{array}{c}-0.240 * * * \\
(0.022)\end{array}$ & $\begin{array}{c}-0.270 * * * \\
(0.046)\end{array}$ & $\begin{array}{c}-0.449 * * * \\
(0.032)\end{array}$ & $\begin{array}{c}-0.349 * * * \\
(0.049)\end{array}$ & $\begin{array}{c}0.082 * * \\
(0.036)\end{array}$ \\
\hline Polity $_{t-1}$ & $\begin{array}{c}-0.092 * * * \\
(0.019)\end{array}$ & $\begin{array}{c}-0.077 * * \\
(0.032)\end{array}$ & $\begin{array}{c}-0.169 * * * \\
(0.020)\end{array}$ & $\begin{array}{c}-0.145^{* * *} \\
(0.033)\end{array}$ & $\begin{array}{l}0.042 * \\
(0.025)\end{array}$ \\
\hline $\begin{array}{c}\text { GDP per } \\
\text { Capita }(\ln )_{t-1}\end{array}$ & $\begin{array}{c}0.219 * * * \\
(0.074)\end{array}$ & $\begin{array}{l}-0.175 \\
(0.139)\end{array}$ & $\begin{array}{c}-0.466 * * * \\
(0.100)\end{array}$ & $\begin{array}{c}-0.449 * * * \\
(0.143)\end{array}$ & $\begin{array}{c}0.839 * * * \\
(0.110)\end{array}$ \\
\hline $\begin{array}{l}\text { Population } \\
\quad(\ln )_{t-1}\end{array}$ & $\begin{array}{c}-0.243 * * \\
(0.097)\end{array}$ & $\begin{array}{l}-0.013 \\
(0.206)\end{array}$ & $\begin{array}{c}0.145 \\
(0.142)\end{array}$ & $\begin{array}{c}0.284 \\
(0.217)\end{array}$ & $\begin{array}{c}-0.873 * * * \\
(0.164)\end{array}$ \\
\hline British & $\begin{array}{c}1.082 * * * \\
(0.137)\end{array}$ & $\begin{array}{c}2.444 * * * \\
(0.357)\end{array}$ & $\begin{array}{c}2.178 * * * \\
(0.209)\end{array}$ & $\begin{array}{c}2.617 * * * \\
(0.407)\end{array}$ & $\begin{array}{l}-0.410 \\
(0.276)\end{array}$ \\
\hline France & $\begin{array}{c}2.053 * * * \\
(0.119)\end{array}$ & $\begin{array}{l}-0.044 \\
(0.171)\end{array}$ & $\begin{array}{c}-2.235^{* * *} \\
(0.141)\end{array}$ & $\begin{array}{c}-1.167 * * * \\
(0.186)\end{array}$ & $\begin{array}{c}0.182 \\
(0.135)\end{array}$ \\
\hline Portugal & $\begin{array}{c}3.657 * * * \\
(0.241)\end{array}$ & $\begin{array}{c}1.686 * * * \\
(0.418)\end{array}$ & $\begin{array}{c}0.793 * * * \\
(0.247)\end{array}$ & $\begin{array}{c}2.093 * * * \\
(0.447)\end{array}$ & $\begin{array}{c}-1.620 * * * \\
(0.342)\end{array}$ \\
\hline $\begin{array}{c}\text { Age of } \\
\text { Respondent }\end{array}$ & $\begin{array}{c}0.005 * * * \\
(0.001)\end{array}$ & $\begin{array}{c}0.009 * * * \\
(0.002)\end{array}$ & $\begin{array}{c}0.012 * * * \\
(0.002)\end{array}$ & $\begin{array}{c}0.010 * * * \\
(0.002)\end{array}$ & $\begin{array}{c}0.001 \\
(0.002)\end{array}$ \\
\hline $\begin{array}{c}\text { Gender of } \\
\text { Respondent }\end{array}$ & $\begin{array}{c}0.090 * * * \\
(0.034)\end{array}$ & $\begin{array}{c}0.059 \\
(0.039)\end{array}$ & $\begin{array}{c}0.063 \\
(0.042)\end{array}$ & $\begin{array}{c}0.124 * * * \\
(0.036)\end{array}$ & $\begin{array}{c}-0.131 * * * \\
(0.048)\end{array}$ \\
\hline $\begin{array}{c}\mathrm{N} \\
\text { Log likelihood }\end{array}$ & $\begin{array}{c}21,244 \\
-27652.231\end{array}$ & $\begin{array}{c}20,942 \\
-27574.331\end{array}$ & $\begin{array}{c}21,138 \\
-26560.709\end{array}$ & $\begin{array}{c}21,339 \\
-28048.71\end{array}$ & $\begin{array}{c}20,833 \\
-27545.826\end{array}$ \\
\hline
\end{tabular}


Clustered standard errors in parentheses $* * * \mathrm{p}<0.01, * * \mathrm{p}<0.05, * \mathrm{p}<0.1$

The results in Table 4 provide support for the first hypothesis, indicating that the occurrence of conflict events targeting the central government do not impact, in either direction, the public's view of the judiciary, although this non-zero effect is tempered by the occurrence of events targeting a regional government, which indicates a negative relationship with trust in the judiciary. Similarly, Hypothesis 2 finds support in these empirics, which show a negative influence of events targeting both central and regional governments on the public's confidence in the presidency or the legislature. Thus, the occurrence of social conflict centered around grievances against a governing entity has a deleterious effect on the public's confidence in the political institutions of the state.

An additional interesting effect evidenced in Table 4 is the effect of social conflict on the support domestic audiences repose in a state's political parties. Although the analysis in the sample of Latin American states did not yield a statistically significant effect at conventional levels, the analyses in Table 4 indicate that social conflict events directed at either the central or regional government have a deleterious effect on the public's trust in the ruling party. This effect would be consistent with the logic underlaying Hypothesis 2 in that the genesis of the conflict is likely found in the public's opposition to a policy enacted or action omitted by the political actors of a state's government, which will likely be attributed to the activity or omission of the ruling party. Following this reasoning, it is not surprising that the effect of social conflict events targeting the central government lead to a positive increase in the public's trust in a state's opposition party. Thus, social conflict appears to influence the party politics of a state in addition to affecting the public perspective of executives, legislatures, and parliaments.

Alongside the influences of social conflict on the public's trust in its state's institutions, the variables measuring variation across legal institutions exhibit interesting effects, as well. First, judicial independence operates in the manner expected by Hypothesis 3, indicating that the more independent a court, the higher the level of trust reposed in that institution. ${ }^{6}$ Alongside considerations of judicial independence, the scope of the sample across

\footnotetext{
${ }^{6}$ Similar to the results in Table 3, the effect of judicial independence is positive toward non-judicial actors, however, in the models centered on levels of trust across states in Africa, the positive effect of judicial independence increases trust in the presidency and the ruling party yet does not have a statistically significant effect on levels of trust in the legislature or parliament.
} 
the models in Table 4 allows for variation in the types of domestic legal systems, allowing an analysis of how different legal contexts may impact institutional trust. Given the literature identifying a link between common law systems and high levels of judicial independence, one expectation arising from the analysis is that non-common law systems should be less likely to engender trust of the judiciary relative to common law states (see Mitchell, et al. 2013). At least for the distinction between common law and civil law systems, the expectation holds; however, Islamic law systems have a positive effect on trust in the judiciary when compared to common law systems. To further investigate the effect of the institutional context on the public's trust in the judiciary, I calculate the marginal effects of judicial independence and domestic legal systems on the different levels of institutional trust, and the results are presented in Figure 1.

\section{Figure 1: Marginal effects regarding trust in the judiciary}
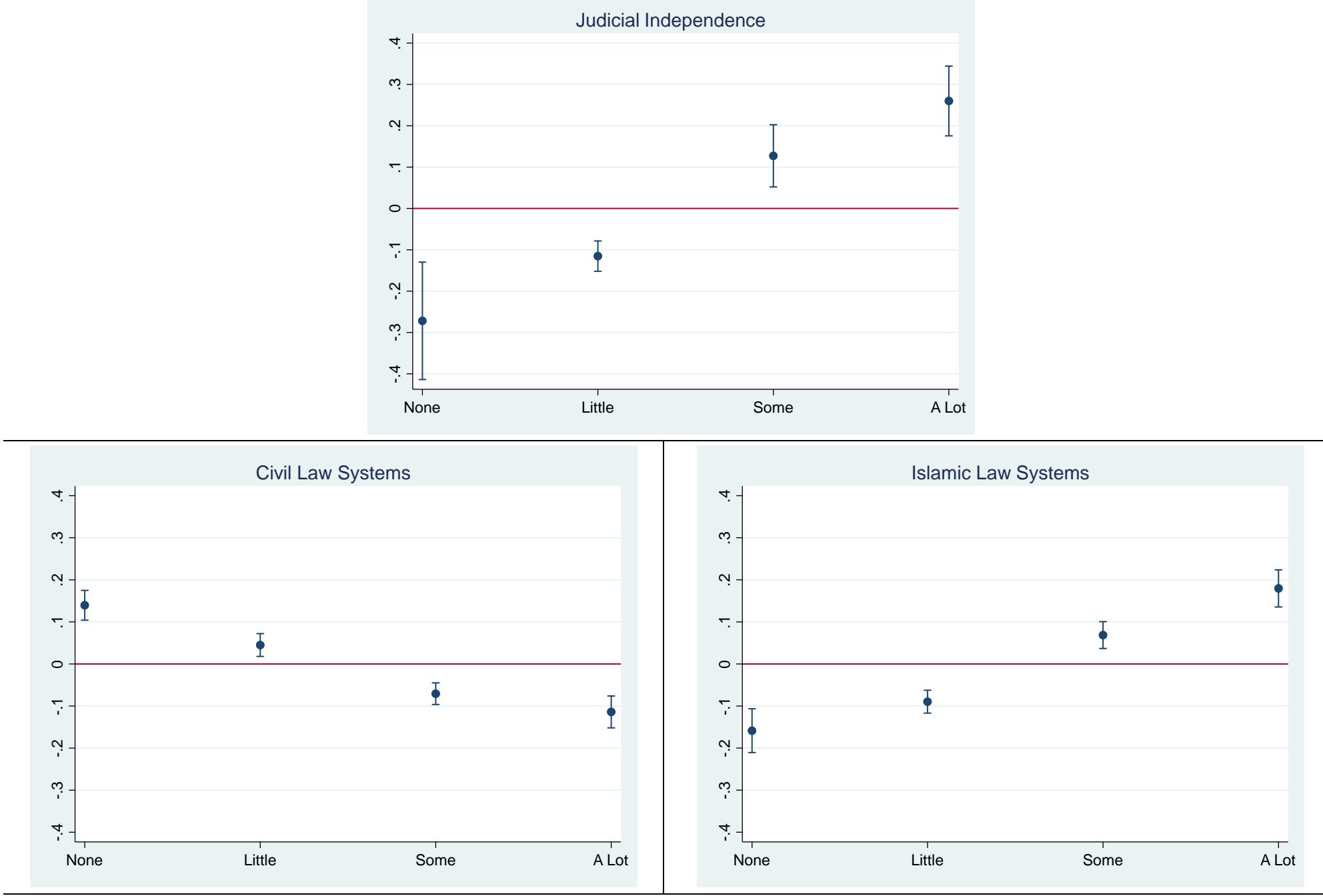

${ }^{\text {Note }}$ The marginal effects in Figure 1 were calculated while holding all continuous variables at their means and the discrete variables at their modal categories. However, the number of central-government targeted events was held at " 0 " and regional-government targeted events at "1." 
In terms of judicial independence, when a domestic judiciary enjoys the highest level of judicial independence, it reduces the likelihood of complete distrust of the institution by nearly $30 \%$; however, the heights of judicial independence lead to a $30 \%$ increase in the propensity of individuals to repose the greatest amount of trust in the institution. These substantive effects reveal the importance judicial independence has for the efficacy, influence, and power of domestic judiciaries, considering the power of courts relies, in part, on the ability to marshal public support to ensure that non-judicial actors enforce or comply with judicial pronouncements. The effect of domestic legal systems is more muted than considerations of judicial independence; nevertheless, they remain important factors in the analysis. In terms of civil law systems, they exhibit an approximately $15 \%$ increase in the likelihood that individuals would report complete distrust in the judiciary, with a corresponding roughly $12 \%$ decrease in high levels of trust as compared to individuals in common law systems. The effect is reversed in Islamic law systems, wherein members of the public would be almost $20 \%$ more likely to express trust in the judiciary and $15 \%$ less likely to note complete distrust as compared to domestic audiences in common law systems. Taken together, these results reflect the importance of the institutional setting in which domestic judiciaries operate when attempting to understand the factors that engender or impede public trust in states' legal institutions.

\section{CONCLUSION}

As Ginsburg and Moustafa (2008) describe, judiciaries have played an increasingly larger role in the domestic affairs of states in recent decades. Given the growing power and prominence of courts, across regime types, it becomes important for scholars to understand how these institutions operate. One foray into this area analyzes how domestic audiences view their judiciaries in relation to the political actors in the system. Are judicial actors unique and institutionally different from non-judicial actors, and if so, does this distinctiveness lead public audiences to view judicial institutions different than political institutions? The findings herein provide initial evidence that domestic audiences seemingly view courts as unique institutions when compared to executives and legislatures. These differences appear to render judiciaries less susceptible to fluctuations in public support stemming from social conflict as compared to the trust reposed in the political institutions of government. Moreover, the institutional context plays an important role in impacting the public's trust in the judiciary, with higher levels of 
judicial independence increasing the likelihood of the public noting high levels of trust in the judiciary.

These analyses do not foreclose additional research on the issue; rather, they open the inquiry to a field of additional research questions. First, this study focuses on 8 Latin American states and 20 states in Africa. Alongside this selection of states based on available data, scholars have generated similar data for other regions in the world, including the Middle East, South America, Europe, and Asia. In addition, the World Values Survey provides global, crossnational survey data on a multitude of issues pertaining to political life (Inglehart, et al. 2014). Given the scope of these data, subsequent research should investigate whether the findings herein are generalizable throughout the global community. Moreover, this study's analyses leverage single cross-sections of the Latinobarómetro and Afrobarometer surveys, and future research can leverage the additional rounds of these surveys to create a panel series to test for over-time effects (Lebo and Weber 2015).

Alongside expanding the sample to include data from additional states in the global community and over-time observations, subsequent research can delve further into the heterogenous effects of legal institutional settings on the public's trust in the judiciary. In particular, the empirics suggest that the nature of a state's domestic legal system has an important influence on public perceptions of the domestic judiciary, and the findings provide a result that is unexpected in light of previous research on the influence of judicial independence, that is, individuals in Islamic law systems are more likely to report high levels of trust in the judiciary relative to those living in common law systems. Investigating the nuance inherent to the institutional differences across legal systems will provide a greater understanding in how the operation of a domestic legal system can affect the judiciary's level of support from domestic audiences (see, e.g., Powell 2013; Powell and Wiegand 2010).

An additional avenue of research can delve into the salience of court activity, that is, whether domestic audiences are concerned more with specific policy outputs or whether concerns over effectiveness, availability, and constraints are the preeminent interests of individuals deciding whether to support their domestic judiciary (see Levi, et al. 2009). The implication of this division may alter the impact of ideology in a comparative setting, while also raising the question as to whether a tipping point is reached when concerns over the judiciary's effectiveness to restrain other actors is superseded by concerns over public policy. 
Not only are these areas fertile ground for expanding our knowledge of judicial politics and institutions, they necessitate answers given the important role public support plays in the strength of courts. Despite an absence of enforcement power, courts harbor the potential to be strong, important players in the direction of a state's political affairs; however, the willingness of non-judicial actors to acquiesce to judicial pronouncements often turns on the degree of public reprimand should non-judicial actors fail to comply with or enforce judicial rulings. In other words, courts need the public and the public needs courts. If the strength of courts turns on public perceptions, it is important to understand how and why individuals would treat the judiciary separate from the political actors in government. Difference creates strength, and in so doing, courts protect the interests of those from whom they derive their power.

\section{REFERENCES BIBLIOGRAPHIC}

Afrobarometer Data, Round 4 (2010), available at http://www.afrobarometer.org.

Aspinall, Edward. "The Construction of Grievance: Natural Resources and Identity in a Separatist Conflict." Journal of Conflict Resolution 51(6) (2007): 950-972.

Bailey, Michael A., and Forrest Maltzman. The Constrained Court: Law, Politics, and the Decisions Justices Make (2011), Princeton, NJ: Princeton University Press.

Bartels, Brandon L. "The Constraining Capacity of Legal Doctrine on the U.S. Supreme Court." American Political Science Review 103(3) (2009): 474-495.

Bartels, Brandon L., and Christopher D. Johnston. "On the Ideological Foundations of Supreme Court Legitimacy in the American Public." American Journal of Political Science 57(1) (2013): 184-199.

Bickel, Alexander M (1962) The Least Dangerous Branch. Indianapolis, IN: Bobbs Merrill.

Boateng, Francis D., and Samuel Adjorlolo. "Judicial Trustworthiness in Africa: Do MacroLevel Conditions Matter?" Crime \& Delinquency (2018): 1-22.

Buhlmann, Marc, and Ruth Kunz. "Confidence in the Judiciary: Comparing the Independence and Legitimacy of Judicial Systems." West European Politics 34(2) (2011): 317-345.

Caldeira, Gregory A., and James L. Gibson. "The Etiology of Public Support for the Supreme Court." American Journal of Political Science 36(3) (1992): 635-664.

Carrubba, Clifford J., Matthew Gabel, and Charles Hankla. "Judicial Behavior under Political Constraints: Evidence from the European Court of Justice." American Political Science Review 102(4) (2008): 435-452. 
Carter, Danielle. "Data Codebook for Round 4 Afrobarometer Surveys in 20 African Countries." Afrobarometer (2010).

Cederman, Lars-Erik, Andreas Wimmer, and Brian Min. "Why Do Ethnic Groups Rebel? New Data and Analysis." World Politics 62(1) (2010): 87-119.

Clark, Tom S. "The Separation of Powers, Court Curbing, and Judicial Legitimacy." American Journal of Political Science 53(4) (2009): 971-989.

Collier, Paul, and Anke Hoeffler. "Greed and Grievance in Civil War." Oxford Economic papers 56(4) (2004): 563-595.

Crowe, Justin. Building the Judiciary: Law, Courts, and the Politics of Institutional Development (2012), Princeton, NJ: Princeton University Press.

Dancy, Geoff, and Veronica Michel. "Human Rights Enforcement from Below: Private Actors and Prosecutorial Momentum in Latin America and Europe." International Studies Quarterly 60 (2016): 173-188.

Driscoll, Amanda, and Michael J. Nelson. "There Is No Legitimacy Crisis: Support for Judicial Institutions in Modern Latin America." Revista SAAP 12(2) (2018): 361-377.

Fariss, Christopher. "Respect for Human Rights Has Improved Over Time: Modeling the Changing Standard of Accountability." American Political Science Review 108(2) (2014): 297 318.

Fearon, James D., and David D. Laitin. "Ethnicity, Insurgency, and Civil War." American Political Science Review 97(1) (2003): 75-90.

Flores, Edward, and Irfan Nooruddin. "Democracy under the Gun: Understanding Postconflict Economic Recovery.” Journal of Conflict Resolution 53(1) (2009): 3-29.

Fox, Justin, and George Vanberg. "Narrow versus Broad Judicial Decisions." Journal of Theoretical Politics 26(3) (2014): 355-383.

Franklin, Charles H., and Liane C. Kosaki. "Republican Schoolmaster: The U.S. Supreme Court, Public Opinion, and Abortion." American Political Science Review 83(3) (1989): 751771.

Gates, Scott, Benjamin A.T. Graham, Yonatan Lupu, Havard Strand, and Kaare W. Strom. "Power Sharing, Protection, and Peace." The Journal of Politics 78(2) (2016): 512-526.

Gibler, Douglas M., and Kirk A. Randazzo. "Testing the Effects of Independent Judiciaries on the Likelihood of Democratic Backsliding." American Journal of Political Science 55(3) (2011): 696-709.

Gibson, James L. "Reassessing the Institutional Legitimacy of the South African Constitutional Court: New Evidence, Revised Theory." Politikon 43(1) (2016): 53-77. 
Gibson, James L., and Gregory A. Caldeira. "Has Legal Realism Damaged the Legitimacy of the U.S. Supreme Court?" Law \& Society Review 45(1) (2011): 195-219.

Gibson, James L., and Gregory A. Caldeira. Citizens, Courts, and Confirmations: Positivity Theory and the Judgments of the American People (2009), Princeton, NJ: Princeton University Press.

Gibson, James L., and Gregory A. Caldeira. "Defenders of Democracy? Legitimacy, Popular Acceptance, and the South African Constitutional Court." Journal of Politics 65(1) (2003): 130 .

Gibson, James L., and Michael J. Nelson. "Is the U.S. Supreme Court's Legitimacy Grounded in Performance Satisfaction and Ideology?" American Journal of Political Science 59(1) (2015): 162-174.

Gibson, James L., Milton Lodge, and Benjamin Woodson. "Losing, but Accepting: Legitimacy, Positivity Theory, and the Symbols of Judicial Authority." Law \& Society Review 48(4) (2014): 837-866.

Ginsburg, Tom, and Tamir Moustafa. Rule by Law: The Politics of Courts in Authoritarian Regimes (2008), Cambridge, UK: Cambridge University Press.

Gleditsch, Nils Petter, Peter Wallensteen, Mikael Eriksson, Margareta Sollenberg, and Havard Strand. “Armed Conflict 1946-2001: A New Dataset." Journal of Peace Research 39(5) (2002): 615-637.

Hall, Matthew E.K. The Nature of Supreme Court Power (2011), New York City, NY: Cambridge University Press.

Hamilton, Alexander. "Federalist No. 78." In Michael A. Genovese (ed.), The Federalist Papers: Alexander Hamilton, James Madison, and John Jay (2009): 235-240. New York City, NY: Palgrave Macmillan.

Helmke, Gretchen. Courts under Constraints: Judges, Generals, and Presidents in Argentina (2012), New York City, NY: Cambridge University Press.

Helmke, Gretchen. "The Logic of Strategic Defection: Court-Executive Relations in Argentina under Dictatorship and Democracy." American Political Science Review 96(2) (2002): 291303.

Helmke, Gretchen, and Frances Rosenbluth. "Regimes and the Rule of Law: Judicial Independence in Comparative Perspective." Annual Review of Political Science 12 (2009): 345366.

Hensel, Paul R. "ICOW Colonial History Data Set, Version 1.0." Issue Correlates of War Project (2014), available at http://www.paulhensel.org/icowcol.html. 
Inglehart, R., C. Haerpfer, A. Moreno, C. Welzel, K. Kizilova, J. Diez-Medrano, M. Lagos, P. Norris, E. Ponarin \& B. Puranen et al. (eds.). 2014. World Values Survey: Round Six - CountryPooled Datafile Version: http://www.worldvaluessurvey.org/WVSDocumentationWV6.jsp. Madrid, JD Systems Institute.

Kapiszewski, Diana. High Courts and Economic Governance in Argentina and Brazil (2012), New York City, NY: Cambridge University Press.

Keith, Linda C. Political Repression: Courts and the Law (2012), Philadelphia, PA: University of Pennsylvania Press.

Keith, Linda C. "Constitutional Provisions for Individual Human Rights (1977-1996): Are They More Than Mere 'Window Dressing?'” Political Research Quarterly 55(1) (2002): 111-143.

Krehbiel, Jay N. "The Politics of Judicial Procedures: The Role of Public Oral Hearings in the German Constitutional Court." American Journal of Political Science 60(4) (2016): 990-1005.

Larkins, Christopher. "Judicial Independence and Democratization: A Theoretical and Conceptual Analysis.” American Journal of Comparative Law 44(4) (1996): 605-626.

Latinobarómetro (2010), available at http://www.latinobarometro.org/latContents.jsp.

Law, David S., and Mila Versteeg. "Constitutional Variation among Strains of Authoritarianism." In Tom Ginsburg and Alberto Simpser (eds.), Constitutions in Authoritarian Regimes (2014), Cambridge: Cambridge University Press.

Lebo, Matthew J., and Christopher Weber. "An Effective Approach to the Repeated CrossSectional Design.” American Journal of Political Science 59(1) (2015): 242-258.

Levi, Margaret, Audrey Sacks, and Tom Tyler. "Conceptualizing Legitimacy, Measuring Legitimating Beliefs.” American Behavioral Scientist 53(3) (2009): 354-375.

Linz, Juan J., and Alfred Stepan. Problems of Democratic Transition and Consolidation: Southern Europe, South America, and Post-Communist Europe (1996), Baltimore, MD: The John Hopkins University Press.

Linzer, Drew A., and Jeffrey K. Staton. "A Global Measure of Judicial Independence, 19482012." Journal of Law and Courts 3(2) (2015): 223-256.

Loyle, Cyanne E., and Benjamin J. Appel. "Conflict Recurrence and Postconflict Justice: Addressing Motivations and Opportunities for Sustainable Peace." International Studies Quarterly 61(3) (2017): 690-703.

Marshall, Monty G; Ted R Gurr \& Keith Jaggers (2018) Polity IV project: Political regime characteristics and transitions, 1800-2017. Center for Systemic Peace (http://www.systemicpeace.org/inscr/p4manualv2017.pdf). 
Michel, Veronica, and Kathryn Sikkink. "Human Rights Prosecutions and the Participation Rights of Victims in Latin America." Law and Society Review 47(4) (2013): 873-907.

Mishler, William, and Reginald S. Sheehan. "The Supreme Court as a Countermajoritarian Institution? The Impact of Public Opinion on Supreme Court Decisions." American Political Science Review 87(1) (1993): 87-101.

Mitchell, Sara M., and Emilia J. Powell. Domestic Law Goes Global: Legal Traditions and International Courts (2011), Cambridge, UK: Cambridge University Press.

Mitchell, Sara M., Jonathan J. Ring, and Mary K. Spellman. "Domestic Legal Traditions and States? Human Rights Practices.” Journal of Peace Research 50(2) (2013): 189-202.

Moustafa, Tamir. "Law and Courts in Authoritarian Regimes." Annual Review of Political Science 10 (2014): 281-299.

Moustafa, Tamir. The Struggle for Constitutional Power: Law, Politics, and Economic Development in Egypt (2007), Cambridge, UK: Cambridge University Press.

Poe, Steven C., C. Neal Tate, and Linda Camp Keith. "Repression of the Human Right to Personal Integrity Revisited: A Global Cross-National Study Covering the Years 1976-1993." International Studies Quarterly 43(2) (1999): 291-313.

Poe, Steven C., and C. Neal Tate. "Repression of Human Rights to Personal Integrity in the 1980s: A Global Analysis.” American Political Science Review 88(4) (1994): 853-872.

Powell, Emilia J. "Islamic Law States and the International Court of Justice." Journal of Peace Research 50(2) (2013): 203-217.

Powell, Emilia J., and Krista E. Wiegand. "Legal Systems and Peaceful Attempts to Resolve Territorial Disputes." Conflict Management and Peace Science 27(2) (2010): 129-151.

Powell, Emilia J., and Jeffrey K. Staton. "Domestic Judicial Institutions and Human Rights Treaty Violation.” International Studies Quarterly 53(1) (2009): 149-174.

Randazzo, Kirk A., Douglas M. Gibler, and Rebecca Reid. "Examining the Development of Judicial Independence.” Political Research Quarterly 69(3) (2016): 583-593.

Ruibal, Alba M. "Self-Restraint in Search of Legitimacy: The Reform of the Argentine Supreme Court.” Latin American Politics and Society 51(3) (2009): 59-86.

Salehyan, Idean, and Christopher Linebarger. "Elections and Social Conflict in Africa, 19902009.” Studies in Comparative International Development 50(1) (2014): 23-49.

Salehyan, Idean, Cullen S. Hendrix, Jesse Hamner, Christina Case, Christopher Linebarger, Emily Stull, and Jennifer Williams. "Social Conflict in Africa: A New Database." International Interactions 38(4) (2012): 503-511. 
Salzman, Ryan, and Adam Ramsey. "Judging the Judiciary: Understanding Public Confidence in Latin American Courts." Latin American Politics and Society 55(1) (2013): 73-95.

Segal, Jeffrey A., Chad Westerland, and Stefanie A. Lindquist. "Congress, the Supreme Court, and Judicial Review: Testing a Constitutional Separation of Powers Model." American Journal of Political Science 55(1) (2011): 89-104.

Segal, Jeffrey A., and Harold J. Spaeth. The Supreme Court and the Attitudinal Model Revisited (2003), Cambridge, UK: Cambridge University Press.

Segal, Jeffrey A. "Separation-of-Powers Games in the Positive Theory of Congress and Courts." American Political Science Review 91(1) (1997): 28-44.

Sikkink, Kathryn. The Justice Cascade: How Human Rights Prosecutions Are Changing Politics (2011), New York City, NY: W.W. Norton \& Company, Inc.

Staton, Jeffrey K. "Constitutional Review and the Selective Promotion of Case Results." American Journal of Political Science 50(1) (2006): 98-112.

Vanberg, Georg. The Politics of Constitutional Review in Germany (2004), New York City, NY: Cambridge University Press.

Vanberg, Georg. "Legislative-Judicial Relations: A Game-Theoretic Approach to Constitutional Review." American Journal of Political Science 45(2) (2001): 346-361.

Walker, Lee D. “A Multi-Level Explanation of Mass Support for the Judiciary.” Justice System Journal 37(3) (2016): 194-210.

Wang, Yuhua. Tying the Autocrat's Hands: The Rise of the Rule of Law in China (2015), New York City, NY: Cambridge University Press.

Widner, Jennifer. "Courts and Democracy in Postconflict Transitions: A Social Scientist's Perspective on the African Case." The American Journal of International Law 95(1) (2001): 64-75.

World Bank. "World Development Indicators." Available at https://data.worldbank.org/datacatalog/world-development-indicators.

Submetido em: 08/07/2019

Aceito em: 22/07/2019 